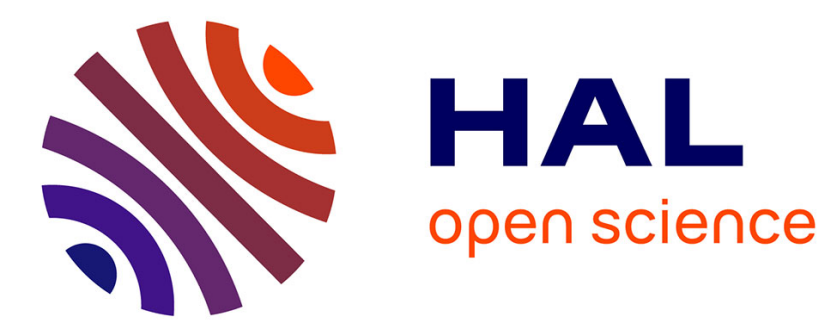

\title{
The Role of Geography in the Northwest China Linguistic Area
}

\author{
Dan $\mathrm{Xu}$
}

\section{To cite this version:}

Dan Xu. The Role of Geography in the Northwest China Linguistic Area. Dan Xu adn Jingqi Fu.

New Studies of Space and Quantification in Languages of China, 2015. hal-01386246

\section{HAL Id: hal-01386246 \\ https://hal.science/hal-01386246}

Submitted on 31 Oct 2016

HAL is a multi-disciplinary open access archive for the deposit and dissemination of scientific research documents, whether they are published or not. The documents may come from teaching and research institutions in France or abroad, or from public or private research centers.

Copyright

L'archive ouverte pluridisciplinaire HAL, est destinée au dépôt et à la diffusion de documents scientifiques de niveau recherche, publiés ou non, émanant des établissements d'enseignement et de recherche français ou étrangers, des laboratoires publics ou privés. 
The Role of Geography in the Northwest China Linguistic Area

Dan Xu

Abstract The frontier regions between Gansu and Qinghai provinces in China form a linguistic area in which Sinitic languages and non-Sinitic languages share similar syntactic features. Geographic factors have undoubtedly played a significant role in causing these neighboring languages to develop parallel characteristics. A phonological feature attested in the Gansu-Qinghai area is the reduced tone system. However cities and surrounding regions show two distinctive patterns in tone evolution. Important cities in Northwestern China form a network which is not necessarily following the spread of tone simplification, while peripheral regions are undergoing a tone reduction process. Sociocultural factors work together with geospatial factors in forming linguistic areas.

Keywords Linguistic area $\bullet$ Geographic distance $\bullet$ City model $\bullet$ Peripheral region model

\section{Introduction}

Languages are closely linked to space since their distribution depends heavily on human migration over the globe. Languages and human genes show a correlation (Cavalli-Sforza 1988; Cavalli-Sforza 2000) even though they do not match up space. Do geographic factors piay a rele in langue evelution? space. Do geographic factors play a role in language evolution? The answer is external motivation for language change, and certain geographic conditions are necessary for language langu which fase, and com gographic condilions are

This work has been supported by the subvention of ANR-12-BSH2-0004-01. D. Xu (四)

65 artement Chine, Institut National des Langues et Civilisations Orientales,

3 Paris, France

CRLAO/IUF, Paris, France

(- Springer International Publishing Switzerland 2015 
These areas cannot exist without space. Some linguistic areas are famous, such as the Balkans Area, which includes a confederation of languages that share linguistic features: Modern Greek (Hellenic Branch), Bulgarian (Slavic Branch), Romanian (Latin branch), and Albanian (Illyric Branch). The Vaupez-Içana basin (Northeast Amazonia) is another well-known linguistic area (Aikhenvald 2002; Aikhenvald and Dixon 2006). Works on linguistic areas include those by Thomason and Kauffman (1988), Enfield (2005), Heine and Kuteva (2005), Bisang (2010) among others. The linguistic area around the borders between Gansu and Qinghai provinces in China' is currently less popular, because most works are written in Chinese. In fact, language contact in China is as significant as in other areas, since differen language families have coexisted for centuries and have interacted intensely. Keit W. Slater (2003), who works on Monguor (Mangghuer) in this region, uses the term "Qinghai-Gansu Sprachbund" while Janhunen (2004) chooses the tem "Amdo Sprachbund" (Amdo dialects form an important group of dialects among Tibetan dialects, see Tournadre 2005: 17)

In the Gansu-Qinghai linguistic anguages are spoken. The region is inhabited by different ethnic groups including people who speak Santa, Bao'an, Monguor and Eastern Yugur, which belong to the Mongolic group of the Altaic family; while others speak Western Yugur, Salar an Kazakh, which are part of the Turkic group in the same farily, and finally, some speak Amdo dialects which are classified within the Tibeto-Buman group in the Sino-Tibetan family. The Chinese language spoken next to or sunounded by then has undergone dramatic changes. This area offers rich samples orlanguage contact for language typology, anthropology and genetic studes. The Hezhou area presents a smaller linguistic area inside the Gansu-Qinghai area. We will obsve the major features found in this region (the Hezhou area), try to understand and analyze why hese features acclong factors work together with linguistic and sociocultural factors.

\section{Gansu-Qinghai Sprachbund}

Linguistic classification is generally based on three different types of criteria: genealogical (similar to biological classification), typological, and linguistic area. Genealogy was used first in biology and then in linguistics. Encouraged by Darwin's

'See Li Charles N. (1983), Ma Shujun (1982, 1984), Li Keyu (1987), Ringdzin Wangmo (1991), Dwyer, Arienne M. (1992), Lanzhou Daxue zhongwenxi Linxia (204), Peyraube (2009) and Xu Dan (2011a, b) among others.

2According to Slater (2003:7), the term of the Gang-Qing Sprachbund was first proposed by Dwyer (1995).

De Hezhou area has clear boundaries in which Sinitic and non-Sinitic languages are spoken. However, the term Hezhou Dialect conventionally refers to Sinitic varieties. theory of evolution (1859), Schleicher (1861) discovered that the evolution of species is similar to that of languages. Nineteenth century linguists successfully applied genealogical methods to the comparison of historic Indo-European languages. Typological studies have developed substantially since Greenberg's works in the 1960s. Today typological methods are a popular approach in linguistic research. Over the past few decades, linguistic areas have drawn the attention of scholars, who have noted that in a given region, languages having unrelated origins often share similar lexical and grammatical features. This approach, i.e. the linguistic area, is used where genealogy and typology fail to analyze unrelated languages which geographically are neighbors in a given region. It is evident that this cannot replace the other two Thenes, since all three are complementary rather than exclusive methods.

The definition of linguistic area varies according to scholars. Emeneau (1956) thinks that a linguistic area is an "area which includes languages belonging to more other members of (at least) one of the families" Thich are found not to belong to the (2002: 7), Enfiel (2005: 182), Heine families "Thomason (2001: 99), Aikhenvald notion. Their main view converges and Kuteva (2005: 172) have also defined this notion. Their main view converges onto the point that in a geographical region, some tures. However these authors ask the same question: how many fentures are minimally required to define one linguistic area? The how many features are miniunanimous. Thomason $(2001: 101)$ has suggested that only one feature is are not distinguish a linguistic area from other regions. This point of view seems difficult to adopt, even though theoretically it is logical and correct. It is generally understo that none of the criteria proposed so far are able to adequately explain the dot Bisang (2010: 428) indicates that "such criteria [number of languages an the data.

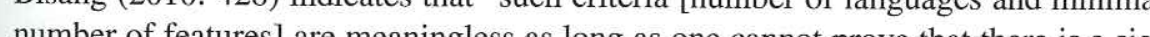
nificant correlation between the exact quantification of languges families or features and either a certain linguistic structure or a certain social pattern present in sever

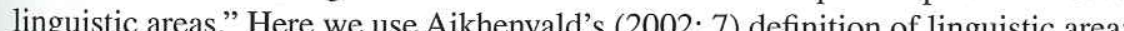

A linguistic area (or Sprachbund) is generally taken to be a geographically delimited area including languages from two or more language families, sharing significant trait (In

As Heine and Kuteva (2005: 177) point out, a linguistic area is a macro-area in which smaller areas could exist. In The pons and Kaufman's (1988) terms, a given area is considered to have "multilateral sprachbund situations". According to Heine and Kuteva, in an ideal linguistic area, languages use different forms but "each form has an exact structural equivalent in other languages

In our target region, the Gansu-Qinghai linguistic area (hereafter Gan-Qing), languages show similar (but not identical) structures which play equivalent grammatical roles, although these structures are the result of replication from differen model languages. It is now known that the zone between Gansu and Qinghai has by Genghis Khan ifferent ethnic groups for centuries. With the victory and control merged, including people from Central Asia. Continuous migrations caused the 
language situation to become more complicated. As presented in the Introduction, languages belonging to the Altaic and Sino-Tibetan families have coexisted and interacted. Though all linguists do not agree with the term "Altaic family", the term is popular and has been adopted in linguistic research. As Norman (1988: 6) remarks, "A few European Turkologists remain skeptical about the Altaic theory, accepted." It is clear that the term has been conventionally accepted by default accepted." It is clear that the term has been conventionally accepted by defaut (2011), we know that the major paternal lineages, as well as the maternal lineages, are quite heterogeneous in Altaic populations. This shows that they have very difare quite heterogeneous in Altaic populations. This shows that hey have atterns in ferent genetic origins. Linguistic data, however, presents very regular patterns in
morphology and syntax. Moreover, the basic vocabulary is consistently attested in morphology and syntax. Moreover, the basic vocabulare subsoups of the Altaic family. How can we deal with the two realities? the three subgroups of the Altaic family. How two datings are in conflict. For biologists (and some linguists), the origin can go back to prehistory, while for most linguists, the time scale cannot go beyond the limits of vocabulary reconstruction. The giant ruler used by biologists has units of 10,000 years, while that of linguists is often limited to hundreds of years. It all heavily depends, in fact, on the period of formation of the "Altaic family". Even if the three subgroups formed due to language contact and borrowing from each other, today the family has been building up for long enough to constitute a unified family for linguistic studies. We cannot ignore the fact that the ancestors of today's Altaic populations were biologically very different. No one can deny the unity of the Chinese language, though it is well known that the genetic origins of the Chinese people are very diverse. Several languages in our target area formed relatively recently (between the thirteenth and seventeenth centuries AD) and the populations' origins are quite heterogeneous. As for the Sino-Tibetan family, it is perhaps more reasonable to take the terms used by Jahunen (2004): "Sinitic sphere" and "Bodic sphere" (Amdo Tibetan and variants), in order to account for diachronic elements.

In this paper, we will focus on the Hezhou area, which is a smaller linguistic are inside the larger Gan-Qing linguistic area. Geographically the boundaries of Hezho are clear; it includes Linxia city, Linxia, Hezheng, Guanghe, and Yongjing countie in Gansu province, and Xunhua, Minhe, Ledu, Tongren and Datong counties in Qinghai province. Hezhou dialect is clearly a Sinitic variety, however scholars have different opinions on the classifications of Whin (spoken at jianzha county in Qinghai province) and Gangou (found in the Minhe county of Qinghai) dialects. The crucial question is what language the people originally spoke. In other words, have these languages been sinicized, altaicized, tibetanicized, or several of these one after another ${ }^{5}$ ?

${ }^{4}$ ahunen (2004: 72) indicates that Sinitic languages in this region include "Hezhou, Tangwang, Gangou, Wutun". The same author in the same paper however shows some doubts about his clas-
sification citing Gangou and Wutun with question mark after Sinitic on page 73 .

'Cf. the monograph on Tangwang (Xu Dan 2014a, Chap. 5) which is thought to be a Sinitic variety heavily colored by Santa (or Dongxiang), a Mongolic language.

Geographically speaking, the Hezhou area contains the zone situated west of the Tao River including several counties in Linxia Hui Autonomous Prefecture, Gansu. Xu Dan (2014a) thinks that the Tangwang language, which was heavily influenced by Santa (Dongxiang), should also be included in Hezhou dialect even though some syntactic features are only attested in Tangwang. Hezhou dialect varieties share the following syntactic and phonological features:

1. The most frequent word order is $\mathrm{OV}^{6}$ while in Mandarin and other dialects the word order is VO.

2. Case marking is attested in Hezhou dialect. In the pronoun system, nominative and accusative are distinct. Nominative is not marked while accusative is marke (See Xu Dan 2008, Xu Dan and Peyraube 2009). The case marking is systematic and full-fledged with accusative, ablative and instrumental markings. Thesc markings are completely alien to Mandarin and other Sinitic varieties.

The plural marking is also different from other Sinitic varieties. It can mark nouns with the human feature (as in other Chinese dialects), as well as noun with the non-aninate feature (including abstract meanings).

. A mophin $\left[\left[_{2}\right]^{8}\right.$ is often used to mark the linking of two clauses; the first verb can contain an object, giving the structure $\mathrm{VO}$ tş $\mathrm{V}$, which is prohibited in In Hezhou as in the Gan

san- Qing area, the verb 'to say' goes at the end of reported speech instead of preceding it. This use is also attested in Mongolic and Amdo

6. In phonology, the sound change shows regular patterns. Some words display Shilar sound changes which are not common in other zones (see details i Zhang Chengcai 2006, Xu Dan (2014a, Chap. 2).

. Another important phonological feature found in the area is the progressive loss of tones. Dialects and Sinitic varieties with two or three tones are concentrated this area. ${ }^{\circ}$ Outside the area, some three-tone languages are also found in other examples will be given in Sect. 3 .

We are aware of the constant influences of Turkic and Mongolic languages from one side and the Amdo language and its varieties from the other side upon the Chinese languages in this area. Some traces of these languages can be identified in

VO order is acceptable in some expressions.

This syntactic and semantic feature can be also found in a few counties in Hebei and Shandong
(see Xu 2011b) but remains a common marking in the Gan The pronunciation varied slightly in the Gan-Qing arest ng does not necessarily match with Hezhou dialect.

IIn Xinjiang and Ningxia, three tone dialects are numerous, but they do not share other features seen in the Gan-Qing area.

"Some Sinitic varieties have even lost tones, such as Wutun (see Janhunen et al. 2008), in Tangwang, monosyllabic words have begun losing their tone among younger generations (see Xu
Dan 2014a, Chap. 2). 
Sinitic languages, which do not possess the same inheritance; these non-Han languages belong to different families and were diachronically unrelated. However they share some typological similarities, such as OV word order and postpositions. Slater (2003: 7-8) remarks that in the Gan-Qing area, "an overall process of structural convergence is affecting all of the regional languages"; that "verb-final word order and other head-final morphosyntax (postposition, suffixes, etc.) spread into Sinitic from neighboring languages". According to him, Mongolic languages in the Gan-Qing area "now have essentially Sinitic phonological systems" (though without full-fledged tone systems). In addition to our own field data in this region, we have noted that language contacts are not unidirectional; both sides, Han languages and non-Han languages, have undergone profound changes over several centuries the phonological and mophosyntactic lo understand why this phenomenon exists.

\section{Why Are Several Features Common in the Area?}

As we have mentioned, several syntactic and phonological features in the area are quite common within Han (Sinitic) languages. Let us compare the main features of Han and non-Han languages in the Hezhou area, in which regular patterns can be found.

The Table 1 suggests that Altaic languages have exerted a stronger influence upon Sinitic languages while Bodic languages show less influence at least in this set of features. Janhunen (2004: 72) indicates that "Features representing the Altaic There (as understood in the typological sense only) are mainly manifested as a sphere (as unifosted as gerescilly

Table 1 Comparison of features in the Hezhou area

\begin{tabular}{|c|c|c|c|}
\hline & Sinitic languages & $\begin{array}{l}\text { Mongolic } \\
\text { languages }\end{array}$ & \begin{tabular}{|l}
$\begin{array}{l}\text { Amdo } \\
\text { languages }\end{array}$ \\
\end{tabular} \\
\hline Word order & OV & OV & OV \\
\hline Genitive + Adj $+N$ & Yes & Yes & No \\
\hline Genitive +N+Adj & No & No & Yes \\
\hline Case marking & Yes & Yes & Yes \\
\hline Ergative marking & No & No & Yes \\
\hline Accusative & Yes & Yes & No \\
\hline $\begin{array}{l}\text { Plural marking is possible } \\
\text { when N[-Animate] }\end{array}$ & Yes & Yes & No \\
\hline 'Say' verb must go after speech & Yes & Yes & Yes \\
\hline Tones & Loss of tones attested & No & $\mathrm{No}^{\mathrm{a}}$ \\
\hline
\end{tabular}

But in St
low tones mutually exclusive. Thus, the Sinitic and Bodic languages of the Sprachbund may be said to share a basic Altaic typological orientation with their Turkic and Mongolic marking, an Altaic language means which is languages have adopted accusative definite. In Amdo as well as in Standard Tibetan, the agent is mobjects are not case instead of tho abject as in Standard inbetan, the agent is marked by ergative have been strongly influenced by Amdo, it is the object which is in Qinghai which sative marker [xa] (see Cheng Xingui (1980) Jia Xiru $(1991,1994)$. Dede (2007) Xu Dan (2014b), among others). The morper Altaic languages, but its function is similar Xu $\mathrm{Xun}$ (2014b) supposes laned from sative marker [xa] came from the Chinese language. Few cases have been reported of ergative marking in Sinitic languages which have intense conte been reported Yixiweisa Acuo (2004) indicates that west of Sichuan Province) and has erative marking like Tibetan (spoken in the (spoken at Jinzha County in Qingai Province), a language which was Sinitic variety and has undergone Tibeta rather than ergative ( $\mathrm{Xu}$ Dan 2014b).

政 result no matter whether they experience Altaic or Bodic language influences? In fact these similar features are due to at least three situations: (a) Language unialready been studied in previous work Chance or coincidence. These factors have add another factor which was less commonly mentioned, (d) Spatial or georaphic factors.

The OV-postposition pattern can be considered as a universal in human languages, as Greenberg (1963) and Dryer (1992)'s investigations indicate. Their research shows that languages with VO word order tend to use prepositions while those with OV word order prefer postpositions. In this case, either Altaic or Bodic languages OV word influenced Sinitic varieties which use VO word order. When the shift to language order begins, postposition use follows. It is worth noting that the Chinese (see Peyraube 1997; Xu 2006). Case marking in Sinitic varieties in this remains VO due to language contact. It seems that case marking is mainly influenced by Altaic anguages, because it is quite different from the case marking strategy seen in Amdaic and Standard Tibetan, even though the function is similar. As for plural marking, we (Xu 2011b) have already studied it in this area, indicating that its use is a mixed result: it is due to both internal evolution in the Chinese language, which is supported by Chinese diachronic documents; and to external factors, in particular the influence of Mongolic languages since the thirteenth century, which is also attested in historical documents. The syntactic position of the verb 'to say' is also not the product of chance. In this area, all non-Han languages display this phenomenon, i.e. placing the verb 'to say' after reported speech. Note however that the language influence is mutual: the typical Chinese model of putting the 'say' verb before reported speech is starting to appear in non-Han languages (see Liu Zhaoxiong 1981). The fact that Sinitic languages which have begun to lose tones are concentrated in this 
area is also due to language contact, but we cannot say that this is the single factor which is causing the loss of tones. In Hebei and Shandong provinces, located more than one thousand kilometers from Gansu (Hebei is around 1,000 km while Shandong is around 1,247 km from Gansu province), simplification of the tone system has been repong others).
among

among others). If some phonological and morpho-syntactic changes in languages of this region have converged into similar features, what has been the centific domains other than geographic factors? Here we would tike to Fording to Tobler's (1970) First Law of linguistics to exple the pure more Geography, "everything is related ever should related than distan". Whis hean also help u be related, especially to understand ling sace can be linked to each olher dith various features. Shen $\mathrm{L}$ isolated and iss (in this volume) linguistic stion or continuu that linguistic ches in the region can have different degrees of change. In other even though words, the qua imost never located between by geographic sites. This means that inside a linguistic area, which could be comtwo adjacent site posed of several s ment of (Sinitic

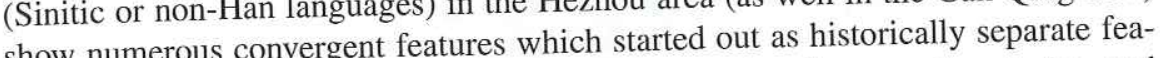
tures. People of different ethnicities have lived together for several centuries, and their their lases graphic factos ine cannot remove social and cultural factors from languages when or asply distar ifferent factors including geographic ones, we will distance. Taking accons patterns of language evolution in which one should distinguish now ent issues in analysis.

Chao (2009) for Lanzhou). It has to be noted that these two cities' speech belong to the Gan-Qing area but not to the Hezhou area. What is interesting is that these two big cities are immediately adjacent to regions where a three-tone system is commonly attested. From Zhang Jiazhuang, Zhuanglang situated to the east of Gansu traveling west, more and more three-tone dialects are found. In Ledu, Xunhua, and Tongren located at the Gan-Qing fronters, which belonging to the Hezhou dialect zone, a three-tone situation is also found. ${ }^{2}$ Other scholars (Luo Peng 1999; Mo Chao and Zhu Fulin 2009; Zhang Jianjun 2009; Xu Dan 2014a, among others) have found two-tone dialects in this area. Let us observe the following table summarizing the distribution of tones in the Gan-Qing area.

A good sketch is often better than a long speech. The above table inventories previous studies by other scholars. The authors of the Gansu fangyan gaikuang (1960) investigated 42 sites in Gansu Province while the authors of the Hanyu fangyan dituji (Cao et al. 2008) studied 15 locations in Gansu and 5 locations in Qinghai. The statistics in this table are drawn from these collective works and statistics by scholars. The authors of the GFGK (1960) had already noticed 22 dialects using three tones and 20 dialects keeping four tones. We can only find three dialects in which the tone number varies according to different authors and periods. In Yuzhong, four tones were reported in 1960 by the GFGK, while three tones were noted in 2003 by Zhang Yanlai. In Tianzhu, the authors of the GFGK (1960) note 4 tones while Deng (2009) counts 3. Zhang (2003) however notes the loss of tone (1 tone means no tone). Again in Wuwei, the authors of the $G F G K$ (1960) and Deng (2009) note 3 tones while Zhang (2003) and Cao et al. (2008) note only two tones. These facts reveal that tones may have evolved, or the locations within a county investigated by previous scholars were not exactly the same. The main tendency is that the tone systems are simplified rather than extended. Three-tone languages have been and continue to be very common in the Gan-Qing area and even four tone dialects have held up very well. In the Hezhou area we investigate in the present paper (Linxia City and Linxia, Hezheng, Guanghe, and Yonging Counties in Gansu Province and Xunhua, Minhe, Ledu, and Tongren in Qinghai $\left.{ }^{13}\right)$, this phenomenon is omnipresent and no exception is found.

It is very interesting to note that Lanzhou, the capital of Gansu, and Xining, the capital of Qinghai, do not follow this tone reduction, even though they are encircled by three-tone dialects. It is clear that here geographic distance plays less of a role than social, political and cultural influences. Larger cities tend to evolve at their own speed and in their own way. Thus we can assume that cities and peripheral regions

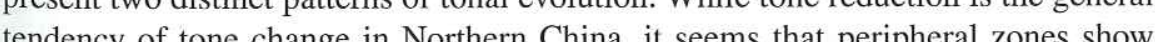

\section{Different Patterns of Language Evolution}

As we have mentioned, two- and three-tone systems are mainly found in the Gan-Qing area. However, Lanzhou, the capital of Gansu province, and Xining, the capital of Qinghai province have maintained a four-tone system like Mandarin spoken in Beijing (see Zhang Chengcai (2006) for Xining and Zhang Wenxuan and Mo ${ }^{12}$ For the moment three-tone dialects are mostly concentrated in Xinjiang. According to Deng
Wenjing (2009), 74 locations have been identified in previous studies, while according to Zhang
Shifang (2000), 66 have been reported. Their statistics are also slightly different for Gansu: Deng Shifang (2000), 66 have been reported. Their statistics are also slightly different for Gansu: Deng
counts 35 while Zhang's statistics are up to 40 . Their statistics are much higher than those provided counts 35 while Zhang's statistics are up to 40 . Their statistics are much higher than those providad.
by Cao et al. (2008) since 20 sites were investigated in Gansu and Qinghai in Cao Zhiyun et al. ${ }^{13} \mathrm{We}$ do not possess data from Datong in Qinghai. 
more regular change than cities, which are bound to undergo changes which are less regular due the thesence of dialects or languages spoken by diverse ethnic groups, and due to migrations of several strata from different periods. The spoken language situation is much more complex in cities, which is caused by continuously moving people with different origins and linguistic, cultural, and religious backgrounds etcetera. That change in cities could be different from its bordering zones seems to be a trivial assumption, while the notion that change in cities is less regular than in peripheral regions may surprise readers. However, this is what we observe in the Gan-Qing area. Other examples can be found in Hebei and Shandong provinces. Beijing, the capital of China, undoubtedly presents an important city in Hebei, and even in the whole country. It is well known that Beijing uses four tones, but it is les. well known that 17 dialects in Hebei (Zhang Shifang 2000) use a three-tone system. In the province of Shandong, the same thing happens again: Jinan, the capital of Shandong uses 4 tones while 22 locations have a three-tone system (see Zhang Shifang's statistics). It is clear that the three-tone system has not affected the fourtone system, which has been well maintained in big cities like Beijing, Jinan, Lanzhou and Xining while their peripheral zones have begun to reduce tones.

Chambers and Trudgillt (1980: 187-189) described how uvular $r$ which first appeared in Parisian French spread through Europe. Wardhaugh 2010 [1986] cited these authors (1998: 170-175) who say that some sound spread in cities and in the countryside surrounding cities presents different rates and modes. ${ }^{14}$ Starting in the seventeenth century, uvular $r$ began to spread from Paris to replace the apical, trilled/flap $r$ in other cities in Europe. "What you find, though, when you plot the progress of uvular $r$, is the importance of cities in its spread. Uvular $r$ seems to be adopted initially by city dwellers, e.g., residents of Bergen and Kristiansand in Norway, The Hague in the Netherlands, Cologne and Berlin in Germany, and Copenhagen in Denmark, and then the new use diffuses outwards. Therefore, the strong internal links in the uvular $r$ area are those between cities, which form a kind of network." Wardhaugh (2010 [1986]: 199). This shows that uvular $r$ spread from city to city and the path of extension could be different for zones outside of cities. Chambers and Trudgillt (1980: 189) indicated that "the diffusion has taken the form of 'jumping' from one urban centre to another". In the north and northwest of China, we observe a similar phenomenon in which cities form a network which is different from their peripheral zones. According to Wardhaugh (2010 [1986]: 199), the uvu$\operatorname{lar} r$ spread "late into the countryside surrounding each city". However what we can see in Northwestern China is the opposite situation. Zhang Shifang (2000: 55) indicates that in Lanzhou and Yuzhong, yang level tone (that is, level tone originating from a voiced initial consonant) and rising tone show "a fusion tendency". This suggests that the three-tone system attested in surrounding regions could affect the city's four-tone system. A decade has passed since this article, and tone fusion in Lanzhou has not yet been reported, but it has occurred in Yuzhong, which is in the suburbs of Lanzhou (see Zhang Yanlai (2003) in Table 2 below). This means that the three-tone system in regions surrounding cities in Northwestern China could influ-

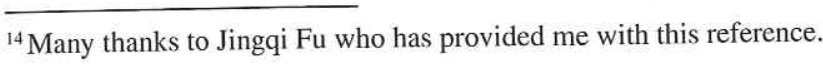

Table 2 Distribution of tones in Gan-Qing area

\begin{tabular}{|c|c|c|}
\hline Locations in Gansu & Tones & Sources \\
\hline 兰州 Lanzhou & 4 & $\begin{array}{l}\text { Gansu Fangyan Gaikuang (1960) (hereafter } \\
\text { GFGK), Zhang Wenxuan and Mo Chao (2009) }\end{array}$ \\
\hline 白银 Baiyin & 4 & GFGK (1960) \\
\hline \multirow[t]{2}{*}{ 榆中县 Yuzhongxian } & 4 & GFGK (1960) \\
\hline & 3 & Zhang Yanlai (2003) \\
\hline 靖远 Jingyuan & 4 & GFGK (1960) \\
\hline 平凉 Pingliang & 4 & GFGK (1960) \\
\hline 泾川 Jingchuan & 4. & GFGK (1960) \\
\hline 镇原 (庆阳) Zhenyuan & 4 & GFGK (1960) \\
\hline 宁县 Ningxian & 4 & GFGK (1960) \\
\hline 庆阳 Qingyang & 4 & GFGK (1960) \\
\hline 环县 Huanxian & 4 & GFGK (1960) \\
\hline 峎县 Minxian & 4 & GFGK (1960) \\
\hline 临潭 Litan & 4 & GFGK (1960) \\
\hline 陇西 Longxi & 4 & GFGK (1960) \\
\hline 武山 Wushan & 4 & GFGK (1960) \\
\hline 徽成(县)Huichang (xian) & 4 & GFGK (1960) \\
\hline 西礼 Xili & 4 & GFGK (1960) \\
\hline 武都 Wudu & 4 & GFGK (1960) \\
\hline 文县 Wenxian & 4 & GFGK (1960) \\
\hline 龙迭 Longdie & 4 & GFGK (1960) \\
\hline \multirow[t]{3}{*}{ 天祝 Tianzhu } & 4 & GFGK (1960) \\
\hline & 3 & Deng Wenjing (2009) (hereafter Deng WJ) \\
\hline & 1 & Zhang Yanlai (2003) (hereafter Zhang YL) \\
\hline 民勤 Minqin & 3 & GFGK (1960), Zhang YL (2003) \\
\hline 永昌 Yongchang & 3 & GFGK (1960), Zhang YL (2003), Deng WJ (2009) \\
\hline 山丹 Shandan & 3 & GFGK (1960), Zhang YL (2003), Deng WJ (2009) \\
\hline 张抆 Zhangye & 3 & GFGK (1960), Zhang YL (2003), Deng WJ (2009) \\
\hline 高台 Gaotai & 3 & GFGK (1960), Zhang YL (2003), Deng WJ (2009) \\
\hline 酒泉 Jiuquan & 3 & GFGK (1960), Zhang YL (2003), Deng WJ (2009) \\
\hline 嘉峪关 Jiayuguan & 3 & GFGK (1960, Deng WJ (2009) \\
\hline E门 Yumen & 3 & GFGK (1960), Zhang YL (2003), Deng WJ (2009) \\
\hline 金塔 Jinta & 3 & Zhang YL (2003), Deng WJ (2009) \\
\hline 民乐 Minle & 3 & Zhang YL (2003), Deng WJ (2009) \\
\hline 临泽 Linze & 3 & Zhang YL (2003), Deng WJ (2009) \\
\hline 骕南 Sunan & 3 & Zhang YL (2003), Deng WJ (2009) \\
\hline 安西 Anxi & 3 & GFGK (1960), Zhang YL (2003), Deng WJ (2009) \\
\hline 敦煌 Dunhuang & 3 & GFGK (1960), Deng Wenjing (2009) \\
\hline 金昌 Jinchang & 3 & Deng Wenjing (2009) \\
\hline 古浪 Gulang & 3 & Zhang YL (2003), Deng WJ (2009) \\
\hline 临洮 Litao & 3 & GFGK (1960), Deng WJ (2009) \\
\hline 定西 Dingxi & 3 & GFGK (1960), Deng WJ (2009) \\
\hline 会宁 Huining & 3 & GFGK (1960), Deng WJ (2009) \\
\hline 通渭 Tongwei & 3 & GFGK (1960), Deng WJ (2009) \\
\hline
\end{tabular}


Table 2 (continued)

\begin{tabular}{|c|c|c|}
\hline Locations in Gansu & Tones & Sources \\
\hline 静宁 Jingning & 3 & GFGK (1960), Deng WJ (2009) \\
\hline 秦安 Tai'an & 3 & GFGK (1960), Deng WJ (2009) \\
\hline 清水 Qingshui & 3 & GFGK (1960), Deng WJ (2009) \\
\hline 天水 Tianshui & 3 & GFGK (1960), Deng WJ (2009) \\
\hline 临夏市 Linxiashi & 3 & GFGK (1960), Deng WJ (2009) \\
\hline 临夏县 Linxiaxian & 3 & Deng WJ (2009) \\
\hline 和政 Hezheng & 3 & GFGK (1960), Deng WJ (2009) \\
\hline 东乡 Dongxiang & 3 & GFGK (1960) \\
\hline 德乌鲁 De'wulu & 3 & GFGK (1960) \\
\hline 广河 Guanghe & 3 & GFGK (1960), Deng WJ (2009) \\
\hline 永靖Yongjing & 3 & GFGK (1960), Deng WJ (2009) \\
\hline 张家庄 Zhangjiazhuang & 3 & Deng WJ (2009) \\
\hline 庄浪 Zhuanglang & 3 & Deng WJ (2009) \\
\hline 康乐 Kangle & 3 & Deng WJ (2009) \\
\hline 永登 Yongdeng & 3 & Zhang YL (2003), Deng WJ (2009) \\
\hline 臭兰 Gaolan & 3 & Deng WJ (2009) \\
\hline 会川 Huichuan & 3 & Mo Chao and Zhu Fulin (2009) \\
\hline 附城 Fucheng & 3 & Mo Chao and Zhu Fulin (2009) \\
\hline 洮阳 Taoyang & 3 & Mo Chao and Zhu Fulin (2009) \\
\hline 康家崖 Kangijaya & 3 & Mo Chao and Zhu Fulin (2009) \\
\hline \multirow{2}{*}{ 武威 Wuwei } & 3 & GFGK (1960), Deng WJ (2009) \\
\hline & 2 & Zhang YL (2003), Cao Zhiyun et al. (2008) \\
\hline $\begin{array}{l}\text { 西固区马家山 Xiguqu } \\
\text { Majiashan }\end{array}$ & 2 & Zhang YL (2003) \\
\hline 红古话 Hongguhua & 2 & Luo Peng (1999), Zhang YL (2003) \\
\hline 海石湾镇 Haishiwanzhen & 2 & Luo Peng (1999) \\
\hline 河嘴乡 Hezuixiang & 2 & Luo Peng (1999) \\
\hline 花庄镇 Huazhuangzhen & 2 & Luo Peng (1999) \\
\hline 平安乡 Pinganxiang & 2 & Luo Peng (1999) \\
\hline 二甲集 Sanjiaji & 2 & Mo Chao and Zhu Fulin (2009) \\
\hline $\begin{array}{l}\text { 永靖县(红泉) Yongjingxian } \\
\text { (Hongquan) }\end{array}$ & 2 & Zhang Jianjun (2009) \\
\hline 唐汗b Tangwang & 2 & Xu Dan (2014a) \\
\hline 西宁 Xining & 4 & Zhang Chengcai (2006) \\
\hline 门源 Menyuan & 3 & Cao Zhiyun et al. (2008) \\
\hline 湟源 Huangyuan & 3 & Cao Zhiyun et al. (2008) \\
\hline 乐都 Ledu & 3 & Cao ZY et al. (2008), Deng WJ (2009) \\
\hline & 3 & Cao Zhiyun et al. (2008), Deng WJ (2009) \\
\hline \multirow{2}{*}{ 民和 Minhe } & 3 & Deng WJ (2009) \\
\hline & 1 & Zhang YL (2003) \\
\hline 循化 Xunhua & 3 & Deng WJ (2009) \\
\hline 贵德 Guide & 3 & Deng WJ (2009) \\
\hline
\end{tabular}

${ }^{a}$ The four-tone dialects are not comprehensive her In Tangwang, Han peop
to distinguish meaning ence cities but not the inverse situation as observed in Europe by the scholar we mentioned. Does tone reduction present a tendency for Northwestern Sinitic languages in the future? Will other dialects or Sinitic languages follow this path? It is too early to predict anything for the moment. ${ }^{15}$

Another fact worth noting is the two-tone system found in Honggu County and Xigu County (Zhang Yanlai 2003), which are part of the suburbs of Lanzhou. Luo Peng (1999) was the first person to note that in Honggu and Huazhuangzhen, suburbs of Lanzhou, people use only two tones. Ten years later, Mo Chao and Zhu Fulin reported that in Sanjiaji, two tones are attested. Separately Zhang Jianjun three-tone system, tho in Hongquan within Yongjing County, which normally uses a Tangwang, located in Dongxiang County, Han people also use two (and thee) tones. The map shown in Fig. 1 clearly indicates that some two-tone use is foe) in a zone geographically close to Dongxiang Autonomous Count in Ge is fond Hui and Tu Autonomous Counties in Minhe, Qinghai province. Slater $(2003: 8,75)$ indicates that the Tu language (See also Zhaonasitu 1981) has a stress system but a tone system. ${ }^{16}$ We understand then that the tone reduction in Hons what has happened in other places near Dongxiang County. These dialects have been profoundly influenced by non-Han languages, i.e. Mongolic or Tibetan languages which do not possess tones.

\section{Concluding Remarks}

In this paper, we have used the linguistic area approach to study a frontier zone between Gansu and Qinghai provinces. The Gan-Qing area is less studied and merits more attention in language contact research. This area includes smaller linguistic areas such as the Hezhou area which have clear geographic limits and salient linguistic features. Geographic factors have played a primordial role in linguistic area formation, since nearby things have more of a chance to be in contact Different ethnic groups speaking various languages show a tendency to develop similar linguistic features over hundreds of years. The situation we can observe today in the Gan-Qing area shows a strong Mongolic influence upon Sinitic languages. Although Sinitic languages exert influence on non-Han languages through lexical borrowing the influence of non-Han languages upon Sinitic languages is much more profound and fundamental: it has begun to affect the syntactic system in Sinitic varieties, even though the borrowing from non-Han languages at the lexical level is not significant (see Chen Naixiong (1989) and Xu Dan (2014a, Chap. 5)).

${ }^{15}$ Most languages investigated by Cao et al. (2008) possess multi-tone system and in the South the
tone system is much more complex than that in the North. ${ }^{16}$ Slater observes that the stress in Tu des not phy a

distinguish meanings of words and Chinese tone begins to influence Tu in its position does no Chinese, but it does not affect the phonological system in this language. 


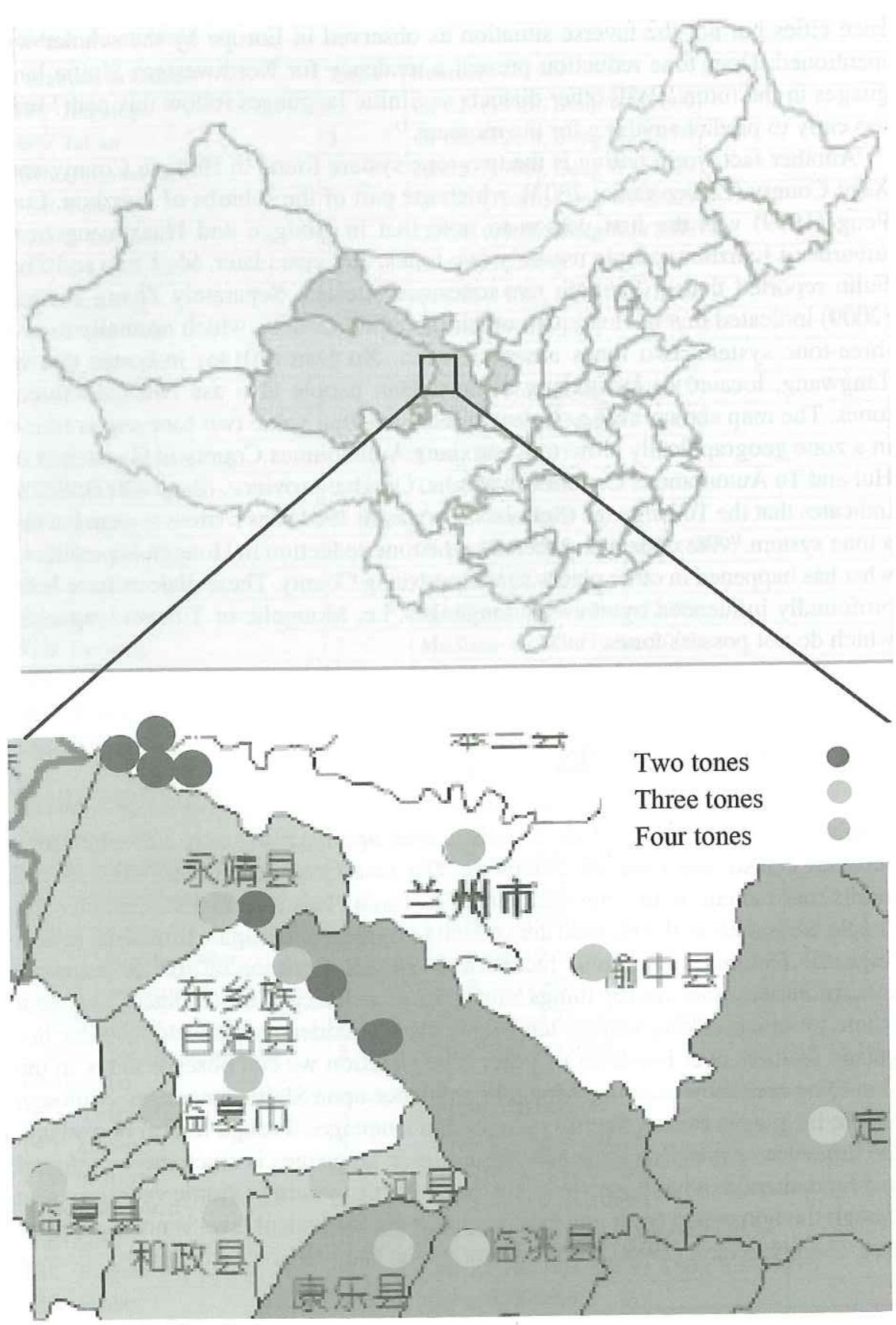

In our study we have also shown that geographic factors have to be taken into account in different ways with respect to cities and peripheral regions. Cities with a significant size form an internal network crossing language boundaries for tone system spread, even though the distance between cities is much bigger than that between them and their surrounding counties. It is shown that cities are sometimes not subject to the same changes undergone by neighboring regions. The neighboring regions show another evolution pattern in which space plays a crucial role. In the past, people thought that constant migration caused languages to evolve more quickly in cities than in the surrounding regions, but the tone simplification attested in Northwestern China presents a counterexample and a challenge.

\section{References}

Aikhenvald, Alexandra Y. 2002. Language contact in Amazonia. New York: Oxford University Press. Aikhenvald, Alexandra Y., and R.M.W. Dixon (eds.). 2006. Areal diffusion and genetic inheriOxford: Oxford University Press.

Bisang, Walter. 2010. Areal language typology. In Language and space. An international han book of ling uistic variation, Theories and methods, vol. 1, ed. Peter Auer and Jürgen E. Schmid,

Cao, Zhiyun et al. 2008. Hanyu fangyan dituji [Atlas of Chinese dialects]. Beijing: Shangwu avalli-Sforza Luigi Luca, Press.

evolution: Bringing together genetic, archaeological, and linguistic data. PNAS 85: 6002-6006.

Cavalli-Sforza, Luigi Luca. 2000. Gene, peoples and languages. London: Penguin Group. Chambers, J.K., and Peter Trudgillt. 1980. Dialectology. Cambridge: Cambridge University Pres.

Cheng, Xianghui. 1980. Qinghai kouyu yufa sanlun [Essay on spoken grammar in Qinghai speech] Zhongguo yuwen [Languages in China] 2: 143-149.

Darwin, Charles. 1859. On the origin of species. London: J. Murray.

Dede, Keith. 2003. The Chinese language in Qinghai. Studia Orientalia 95: 321-346.

Dede, Keith. 2007. The origin of the anti-ergative [xa] in Huangshui Chinese. Language and

Deng, Wenjing. 2009. Xibei diqu san shengdiao fangyan fenbu tedian touxi [Close study on the
distribution of three tones in northwest China]. Lanzhou daxue xuebao [The Lanzhou University Journal] 3: 66-72. Dwyer, Ariene M. 1992. Areenbergian word order correlations. Language 68(1): 81-138. Yellow River Plateau. Dwyer, Arienne M. 1995. From the northwest China Sprachbund: Xunhua Chinese dialect data Yuen Ren Society Treasury of Chinese Dialect Data 1: 143-182. Emeneau, M. 1956. India as a linguistic area. Language 32(1): 3-16. Enfield, N.J. 2005. Areal linguistics and mainland Southeast Asia. Annual Review of Anthropology

列 Normal University (mimeo).

Fig. 1 Map of China and distribution of tones close to Lanzhou 
Heine, Bernd, and Tania Kuteva. 2005. Language contact and grammatical change. Cambridge

Cambridge University Press.
Janhunen, Juha. 2004. [Abstract.] On the hierarchy of structural convergence in the Amdo
(n)

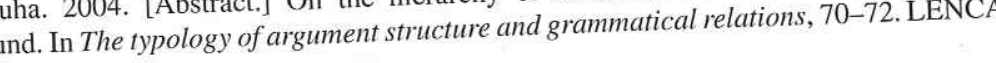

Jank anhunen, Juha, Mar.
Lincom Europa.

jia, Xiru. 1991. Qinghai hanhua yu shaoshu minzu yuyan [Chinese and minority languages in

Jia, Xiru. 1994. Cong Qinghai hanyu de jige fangyan ci kan yuyan jian de jiechu yingxiang. [Impact of language

anzhou Daxue zhongwenxi Linxia fangyan diaocha yanjiuzu, Gansu sheng Linxiazhou wenlian [The Linxia dialects research group in the Department of Chinese at Lanzhou University and Federation of Literary and Arts in Linxia, $\mathrm{D}$

Linxia] Lanzhou: Lanzhuges in contact in western China. Papers in East Asian Languages 1:

Li, Charles

Li, Keyu. 1987. Qinghai hanyu zhong de mouxie A'ertai yuyan chengfe in Qinghai Chinese]. Minzu yuwen [Non-Ha lag se 1, Junyi. 2000. Jiaodonghua sisheng bian san diao de lane a jodong dialects] In Proceedings. and trends of the evolution from four tons andarin dialects, ed. Qian Zengyi, Li Xingjie, 141 145. Qingdao: Qingdao chubanshe [Qingdao Publishing House]. chubanshe [Non-Han language Press].

te hangu fangyan-Lanzhou honggu hua de , Pengyundia [About the dialect having only two tones-phonological system in Honggu dialect shengyundiao XAbout the dialect [Journal of the Normal University of Xibei] 6: 74-77.

Luo, Peng. 2004. Hezhou hua yufa-yuyan jiechu de jieguo [The grammar of Hezhou speech-the result of language contact]. Xibei Shida xuebao [Journal of the Normal University of Xibei] 4 ;
$30-32$.

Ma, Shujun. 1982. Linxia hua zhong de "mingtha" jiegou

lect]. Zhongguo yuwen [Langog hua yu A'ertai yuy [Hezhou dialect and Altaic languages. Ma, Shujun. 1984. Hanyu Hezhou hua yu A'ertai
Minzu yuwen [Non-Han languages] 2: 50-55.

Mo, Chao and Zhu Fulin. 2009. Taohe liuyu hanyu fangyan de yuyin tedian [Characteristics in dialects along the Tao River]. Fangyan [Dialects] 3: 242-340.

Norman, Jerry. 1988. Chinese. Cambridge: Cambridge University Press. 26(1): 3-20.

Peyraube, Alain. 2009. A comparative analysis of the case system in some Northwestern Sinitic languages. Paper $\mathrm{p}$ (forthcoming). Ringdzin Wangmo 亿增汪姆. 1991. Hanyu Hezhou hua yu zangy de [Comparative study
languages] $1: 12-18$.

Cor vergleichenden Grammatik der indogermanischen Sprachen. Cambridge: Cambridge University Press. Shen, Li., Liangzhen Feng, and Hiroshi-shin Tsumura. 2010. Analyzing the dece of referential small mony in Shanxi Hoozhou de Linguistic 14: 137-157.

(1) Slater, Keith W. 2003. A grammar of Mangghuer.
Sprachbund. New York: Routledge Curzon.
Thomason, Sarah Grey. 2001. Language contact-An introduction. Washington: Georgetown University Press.
Thomason, Sarah Grey, and Terrence Kaufman. 1988. Language contact, creolization, and genetic Thomason, Sarah Grey, and Terrence Kaufman.
linguistics. Berkeley/Los Angeles: University of California Press. Tobler, Waldo R. 1970. A comput

Ournadre, Nicolas. 2005. L'aire linguistique tibétaine et ses divers dialectes. Lalies 25: 7-56. Wardhaugh, Ronald. 2010. An introduction to sociolinguistics, 6th ed. Oxford: Blackwel Publishing Ltd.

ei, Lanhai. 2011. Genetic evidence are against a common origin of the Altaic populations Wu. Dan. 2006. Typological change in Chinese syntax. Oxford: Oxford University Press.

Xu, Dan. 2008. Tangwang hua ge biaoji gaikuang [Overview of case marking in Tangwang]. Pape presented at Language Contact Workshop, Pars, Noventer 23. Tngwang]. Zhongouo yuwen Xu, Dan. 2011 a. Tangwang hua de ge biaoji [Case marking in Tangwang]. Znonggno yawe
[Languages in China] 2: 145-154. $\mathrm{Xu}$, Dan. 2011b. Guanyu Hezhou hua ji zhoubian diqu li fei zhiren mingci de fushu biaoji men [About plural marker men [-human] in noun phrase in Hezhou dialect and surrounding areas]. Minzu yuwen [Non-Han languages] 6: 9-23. Xu, Dan. 2014a. Tangwang hua yanjiu [Studies in Tangwang]. Beijing: Minzu chubanshe [NonHan languages Press].
Xu, Dan. 2014b. Ganqing yidai de binge biaoji jiqi leixingxue shang de yiyi [Accusative marker in Gan-Qing languages and their typological significance). In Chengii yu tuoxin-Hanyu yuyan
wenzi xue [nheritance and innovation: Chinese languages and philology], 459-516. Hong Kong: Chinese University of Hong Kong.

$\mathrm{Xu}$, Dan and Alain Peyraube. 2009. Case markers in the Tangwang language. Paper presented the 17th IACL annual conference, Paris, July 2-4.
$\mathrm{Xu}$, Dan, Shaoging Wen and Xiaodong Xie. 2012. Dongxiang yu he Dongxiang ren [Dongxiang language and Dongxiang people]. Minzu yuwen [Non-Han languages] 3: 59-65. language and Dongxiang people]. Minzu yuwen [Non-Han languages]
ixi Weisa 意西微萨阿错. 2004. Daohua yanjiu [Study of the Daohua]. Beijing: Minzu chuban-

she [Non-Han languages Press].
Zhang, Shifang. 2000. Preliminary studies on three tone dialects. Yuyan yanjiu [Language Studies]

4: 48-61. 2003 . Studies on phonetics
Yuyan daxue [University of Languages]. Zhang, Chengcai. 2006. Zhonggu yin yu Qinghai fangyin zihui [Middle Chinese phonology an Publishing House

Zhos Tian daxue [Normal University of Shanxi].

Zhang, Wenxuan and Mo Chao 2009. Lanzhou fangyan cidian [Dictionary of Lanzhou dialect]. [Non-Ha languages Press].

Zhu, Yongzhong, Ujiyediin Chuluu, Keith Slater, and Kevin Stuart. 1997. Gangou Chinese dialectAn comparative study of 